\title{
Antinociceptive and antiinflammatory activities of Adiantum latifolium Lam.: Evidence for a role of IL- $1 \beta$ inhibition
}

\author{
Fabiana Regina Nonato $^{a}$, Tâmara Magalhães Oliveira Nogueira ${ }^{\mathrm{a}}$, Taís Adelita de Almeida Barros ${ }^{\mathrm{a}, \mathrm{b}}$, \\ Angélica Maria Lucchese ${ }^{b}$, Carlos Eduardo Cordeiro Oliveira ${ }^{b}$, Ricardo Ribeiro dos Santos ${ }^{a, c}$, \\ Milena Botelho Pereira Soares ${ }^{\mathrm{a}, \mathrm{c}}$, Cristiane Flora Villarreal ${ }^{\mathrm{a}, \mathrm{d}, *}$
}

\footnotetext{
a Centro de Pesquisas Gonçalo Moniz, Fundação Oswaldo Cruz, Rua Waldemar Falcão 121, CEP 40296-710 Salvador, Bahia, Brazil

b Programa de Pós-Graduação em Biotecnologia, Universidade Estadual de Feira de Santana, Avenida Transnordestina s/n, CEP $44036-900$ Feira de Santana, Bahia, Brazil

${ }^{\mathrm{c}}$ Hospital São Rafael, Av. São Rafael 2152, CEP 41253-190 Salvador, Bahia, Brazil

d Faculdade de Farmácia, Universidade Federal da Bahia, Rua Barão de Geremoabo s/n, CEP 40170-290 Salvador, Bahia, Brazil
}

\section{A R T I C L E I N F O}

\section{Article history:}

Received 20 January 2010

Received in revised form 25 May 2010

Accepted 31 May 2010

Available online $\mathrm{xxx}$

\section{Keywords:}

Adiantum latifolium

Ferns

Antinociception

Antiinflammatory

Interleukin-1 $\beta$

\begin{abstract}
A B S T R A C T
Aim of study: Adiantum, one of the most widely distributed genera of the family Pteridaceae, is employed in folk medicine worldwide. Adiantum latifolium Lam. has been used in Latin American traditional medicine as anxiolytic, analgesic and antiinflammatory. The present study investigates the antinociceptive and antiinflammatory properties of the methanolic extract of Adiantum latifolium (MEA) in animal models of pain and inflammation to confirm its medicinal use.

Material and methods: The antinociceptive and antiinflammatory activities of MEA were evaluated using the writhing, formalin, and tail-flick tests, carrageenan-induced paw edema and arachidonic acid-induced ear edema. Mice motor performance was evaluated in the rota rod test and the acute toxicity evaluated over 14 days.

Results: Intraperitoneal $(1-100 \mathrm{mg} / \mathrm{kg})$ or oral $(100-400 \mathrm{mg} / \mathrm{kg})$ administration of MEA produced a dose-related inhibition of acetic acid-induced writhing in mouse. Furthermore, treatment with MEA $(100 \mathrm{mg} / \mathrm{kg})$ inhibited both the early and late phases of formalin-induced hypernociception. In contrast, MEA $(100 \mathrm{mg} / \mathrm{kg} / \mathrm{IP})$ did not prevent the thermal nociception in the tail-flick test. In addition, MEA (100 and $200 \mathrm{mg} / \mathrm{kg} / \mathrm{IP}$ ) inhibited important events related to the inflammatory response induced by carrageenan or arachidonic acid, namely local edema and increase in tissue interleukin-1 $\beta$ levels. MEA $(300 \mathrm{mg} / \mathrm{kg} / \mathrm{IP})$-treated mice did not show any motor performance alterations. Over the study period of 14 days, there were no deaths or toxic signs recorded in the group of mice given $1000 \mathrm{mg} / \mathrm{kg}$ of MEA. Conclusion: The results demonstrate that Adiantum latifolium has antinociceptive and antiinflammatory activities, acting through the inhibition of IL-1 $\beta$ production.
\end{abstract}

(C) 2010 Elsevier Ireland Ltd. All rights reserved.

\section{Introduction}

Non-steroidal antiinflammatory drugs (NSAIDs) are among the most widely used medications due to their efficacy for a wide range of pain and inflammatory conditions (IMS Health, 2005). However, the long-term administration of NSAID may induce gastro-intestinal ulcers, bleeding, and renal disorders due to their non-selective inhibition of both constitutive (COX-1) and inducible (COX-2) isoforms of the cyclooxygenases enzymes (Robert, 1976;

\footnotetext{
* Corresponding author at: Laboratório de Engenharia Tecidual e Imunofarmacologia, Centro de Pesquisa Gonçalo Moniz, Fundação Oswaldo Cruz, Waldemar Falcão 121 Candeal, CEP 40296-710 Salvador, Bahia, Brazil. Tel.: +55 71 31762260; fax: +55 7131762327

E-mail address: cfv@ufba.br (C.F. Villarreal).
}

Peskar, 1977; Tapiero et al., 2002). On the other hand, fully selective COX-2 inhibitors with reduced gastro-intestinal toxicity have been associated with adverse cardiovascular effects (Dogné et al., 2005). Due of the deleterious side effects attributed to the prolonged use of NSAID and their ineffectiveness in some cases, the control of inflammatory pain is still a major challenge. Nowadays, there has been an enhanced interest in the development of disease-modifying drugs. It is well accepted that cytokines constitute a link between cellular injuries and signs of inflammation, e.g. cell migration, edema, fever, and hyperalgesia (Ferreira et al., 1988; Faccioli et al., 1990; Dinarello, 2000). In contrast to NSAID, inhibitors of cytokine production can exhibit disease-modifying activities (Geiger et al., 1994), representing an improved therapeutic strategy for the control of inflammatory diseases.

Ferns have been considered an excellent source of medicines for a long time (Barros and Andrade, 1997). However, few stud- 
ies concerning Brazilian pteridophyte pharmacological properties have been reported and, in most reports, these plants are called merely ferns or "avenca" (in Portuguese language). Adiantum L. is popularly called "maiden hair fern" because of the shiny black rachis of the leaves. It is one of the most widely distributed genera of the family Pteridaceae and is represented by 63 species in Brazil (Winter et al., 2007). The plants called "avenca" in Brazil represent species of Adiantum L. which are employed in folk medicine worldwide as antiinflammatory, analgesic, antiinfectious, and diuretic (Cambie and Ash, 1994; Barros and Andrade, 1997; Christensen, 1997; Gogoi, 2002; Bresciani et al., 2003). Infusions and compresses of Adiantum latifolium Lam. have been used in Latin American traditional medicine as anxiolytic, analgesic, and antiinflammatory (Barros and Andrade, 1997; Lopez et al., 2001; Bourbonnais-Spear et al., 2007). Adiantum latifolium has been used in Brazil to treat different types of pain, whereas in Colombia it was used for the treatment of cutaneous conditions associated with inflammation and infection (Lopez et al., 2001). It is a terrestrial widespread fern in Tropical Americas that ranges from Mexico to South America, including Central America, Antilles, Colombia, Venezuela, Guayanas, Ecuador, Peru, Bolivia, Brazil, and Paraguay (Moran and Yatskievych, 1995). The present study was undertaken to establish the antinociceptive and antiinflammatory properties of the methanolic extract of Adiantum latifolium leaves (MEA) and to investigate the mechanisms responsible for its effects. In order to discard possible non-specific muscle-relaxant or sedative effects of MEA, mice motor performance and toxicity of MEA were also evaluated.

\section{Materials and methods}

\subsection{Plant material}

Plant specimens were collected in the Atlantic Forest region at Salvador, Bahia State, Brazil, in August, 2006, in authorized areas by IBAMA (Brazilian Institute for the Environment and Natural Resources), and was botanically identified by Dr. Fabiana R. Nonato. A voucher specimen has been deposited at the Herbarium of Universidade Estadual de Feira de Santana, Bahia, Brazil (HUEFS 142949).

\subsection{Preparation of the methanolic extract of Adiantum latifolium leaves}

Air-dried and powdered blades ( $87 \mathrm{~g}$ ) were exhaustively extracted with methanol at room temperature. The solvent was removed under reduced pressure on a rotary evaporator at $40-45^{\circ} \mathrm{C}$, resulting in the crude extract ( $4 \mathrm{~g}, 4.6 \%$ yield).

\subsection{Animals}

Experiments were performed on male Wistar rats (180-200 g) or male Swiss Webster mice (30-35g) from the Animal Facilities of Centro de Pesquisas Gonçalo Moniz. Animals were housed at $24 \pm 1^{\circ} \mathrm{C}$, under a $12: 12 \mathrm{~h}$ light-dark cycle (lights on at 07:00 AM), with free access to chow and tap water until the day of the experiment, when only water was made available to them. Each animal was used only once. Animal care and handling procedures were in accordance with International Association for the Study of Pain guidelines for the use of animals in pain research (Zimmermann, 1983) and the Institutional Animal Care and Use Committee FIOCRUZ (L-029/09). All efforts were made to minimize the number of animals used and any discomfort. All behavioral testing was performed between 8:00 a.m. and 4:00 p.m.

\subsection{Nociceptive tests}

In the present study, the term hypernociception was used to define the decrease in the nociceptive withdrawal threshold, since the pain perception in animals is not obvious.

\subsubsection{Writhing test}

The intraperitoneal and oral antinociceptive doses of MEA were determined in mice using the writhing test. Acetic acid $(0.8 \%, \mathrm{v} / \mathrm{v}$, $10 \mathrm{ml} / \mathrm{kg}$ ) was injected into the peritoneal cavities of mice, which were placed in a large glass cylinder and the intensity of nociceptive behavior was quantified by counting the total number of writhes occurring between 0 and 30 min after the stimulus injection (Collier et al., 1968). The writhing response consists of a contraction of the abdominal muscle together with a stretching of the hind limbs. The antinociceptive activity was expressed as the writhing scores over $30 \mathrm{~min}$.

\subsubsection{Formalin test}

Rats were placed in an open Plexiglas observation chamber for 30 min to accommodate to their surroundings, and then removed for formalin administration. Rats were gently restrained while the dorsum of the hind paw was subcutaneously administered with $50 \mu \mathrm{l}$ of formalin 1\% (1:100 dilution of stock formalin solution, $37 \%$ formaldehyde in $0.9 \%$ saline) using a 30 gauge needle. Following injection, the rat was returned to the observation chamber for a 60 min observation period. A mirror was placed behind the chamber to enable unhindered observation of the formalin-injected paw. Rats were observed from 0 to 10 min (early phase) and from 10 to $60 \mathrm{~min}$ (late phase) and a nociception score was determined for each period by counting the number of flinches of the injected limb during the observation time (Dubuisson and Dennis, 1977). Flinches were discrete and easily quantifiable.

\subsubsection{Tail-flick test}

The tail-flick test (Analgesiometer, Insight, Brazil) in rats was conducted as described elsewhere (D'Amour and Smith, 1941), with minor modifications. Each animal was placed in a ventilated tube with the tail laid across a wire coil which was at room temperature $\left(23 \pm 2^{\circ} \mathrm{C}\right)$. The coil temperature was then raised by the passage of electric current and the latency for the tail withdrawal reflex was measured. The heating was applied to a portion of the ventral surface of the tail $4 \mathrm{~cm}$ from the tip. Each trial was terminated after $6 s$ to minimize the probability of skin damage. Tail-flick latency was measured before (basal) and after the treatment.

\subsection{Paw edema induced by carrageenan in mice}

Carrageenan $(200 \mu \mathrm{g})$ was injected by intraplantar administration in the right hind footpad of mice. The volume of the mice paws was measured with a plesthismometer (Ugo Basile, Comerio, Italy) before (Vb, baseline) and 2, 4, 24, and $48 \mathrm{~h}$ after ( $\mathrm{Vt}$ ), as described previously (Winter et al., 1962). The amount of paw swelling was determined for each mouse and the difference between $\mathrm{Vt}$ and $\mathrm{Vb}$ was taken as the edema value.

\subsection{Ear edema induced by arachidonic acid in mice}

Arachidonic acid (2 mg/ear) was subcutaneously injected into the mice right ear. The thickness of the ears was measured before and $1 \mathrm{~h}$ after the inflammation induction (Young et al., 1984; Crummey et al., 1987) using a digital caliper (Mitutoyo 500-136 CD-6"). The caliper was applied near the tip of the ear just distal to the cartilaginous ridges and the thickness was recorded in $\mu \mathrm{m}$. Edema was expressed as 
the increase in ear thickness due to the inflammatory challenge.

\subsection{Interleukin-1 $\beta$ measurement}

Skin tissues were obtained 1 or $3 \mathrm{~h}$ after the subcutaneous injection of arachidonic acid in the ear or the intraplantar injection of carrageenan, respectively, in mice terminally anaesthetized from each experimental group. Tissue proteins were extracted from $100 \mathrm{mg}$ tissue/ml PBS to which $0.4 \mathrm{M} \mathrm{NaCl}, 0.05 \%$ Tween 20 and protease inhibitors ( $0.1 \mathrm{mM}$ PMSF, $0.1 \mathrm{mM}$ benzethonium chloride, $10 \mathrm{mM}$ EDTA and $20 \mathrm{KI}$ aprotinin $\mathrm{A} / 100 \mathrm{ml}$ ) were added. The samples were centrifuged for $10 \mathrm{~min}$ at $3000 \mathrm{~g}$ and the supernatant was frozen at $-70^{\circ} \mathrm{C}$ for later quantification (Santiago et al., 2006). IL-1 $\beta$ levels were estimated using commercially available immunoassay ELISA kits for mouse IL-1 $\beta$ (R\&D System, Minneapolis, MN, USA), according to the manufacturer's instructions. The results are expressed as picograms of IL-1 $\beta$ per milliliter of protein solution.

\subsection{Acute toxicity}

The method described by Lorke (1983) with slight modification was used to determine the safety of the MEA. Briefly, normal healthy male mice were divided into groups of five mice in each cage. MEA (100 and $1000 \mathrm{mg} / \mathrm{kg}$ ) or vehicle were intraperitoneally administered. Access to food and water, toxic symptoms and the general behavior of mice were observed continuously for $1 \mathrm{~h}$ after the treatment, intermittently for $4 \mathrm{~h}$, and thereafter over a period of $24 \mathrm{~h}$. The mice were further observed for up to 14 days following treatment for any signs of toxicity and mortality.

\subsection{Motor function assay: rota rod}

To evaluate the possible non-specific muscle-relaxant or sedative effects of MEA, mice were submitted to the rota rod task (Vaz et al., 1996). Rota rod apparatus (Insight, Ribeirão Preto, Brazil) consisted of a bar with a diameter of $3 \mathrm{~cm}$, subdivided into five compartments. The bar rotated at a constant speed of 5 revolutions per minute. The animals were selected $24 \mathrm{~h}$ previously by eliminating those mice which did not remain on the bar for two consecutive periods of $120 \mathrm{~s}$. Animals were treated with diazepam $(10 \mathrm{mg} / \mathrm{kg}$ IP), MEA ( $200 \mathrm{mg} / \mathrm{kg} \mathrm{IP}$ ) or vehicle and $40 \mathrm{~min}$ after were placed on a rotating rod. The latency to falling was measured up to $120 \mathrm{~s}$. The results are expressed as the average time(s) the animals remained on the rota rod in each group.

\subsection{Drugs and administration}

Indomethacin, dexamethasone, carrageenan, arachidonic acid, phosphate buffered saline (PBS), Tween 20, phenylmethylsulphonyl fluoride (PMSF), benzamethonium chloride, EDTA, aproptinin $A$, and 3,3',5,5'-tetramethylbenzidine (TMB) were obtained from Sigma Chemical Company (St. Louis, MO, USA). Diazepam was obtained from Cristália (Itapira, São Paulo, Brazil). Indomethacin was dissolved in Tris $\mathrm{HCl} \mathrm{0.1} \mathrm{M} \mathrm{pH} \mathrm{8.0} \mathrm{plus} \mathrm{saline.} \mathrm{Dexamethasone}$ $(1 \mathrm{mg} / \mathrm{ml})$ was dissolved in ethanol ( $10 \%$ in normal saline). Remaining drugs and MEA were dissolved directly in saline. Drugs were administrated by oral (PO), intraperitoneal (IP), or subcutaneous $\mathrm{SC}$ ) routes. The oral administration was performed by gavage.

\subsection{Data analysis}

Data are presented as means \pm S.E.M. of measurements made on 5-9 animals in each group. Comparisons across three or more treatments were made using one-way ANOVA with Tukey's post hoc test or repeated measures two-way ANOVA with Bonferroni's post hoc test, when appropriate. All data were analyzed using the Prism 5.01 computer software (GraphPad, San Diego, USA). Statistical differences were considered to be significant at $P<0.05$.

\section{Results}

\subsection{Antinociceptive effect of MEA}

The antinociceptive activity of MEA was initially evaluated using the writhing test. Intraperitoneal administration of MEA $(1-100 \mathrm{mg} / \mathrm{kg}), 40 \mathrm{~min}$ before the acid injection, produced a significant $(P<0.001)$ and dose-related inhibition of acetic acid-induced abdominal constrictions in mice (Fig. 1A). Indomethacin $(10 \mathrm{mg} / \mathrm{kg}$ IP), a standard NSAID used as positive control, also produced a significant inhibition of acetic acid-induced writhing response. Moreover, oral administration of MEA $(100-400 \mathrm{mg} / \mathrm{kg}) 50 \mathrm{~min}$ before the acid injection also produced a significant $(P<0.001)$ and dose-related inhibition of acetic acid-induced abdominal constrictions in mice (Fig. 1B). Fig. 2 shows the effect of MEA on the formalin-induced hypernociception in rats. Injection of formalin in control animals induced a biphasic flinching response, with the early phase ranging from 0 to $10 \mathrm{~min}$ (Fig. 2A) and the late phase from 10 to $60 \mathrm{~min}$ (Fig. 2B) after the injection. Treatment with MEA $(100 \mathrm{mg} / \mathrm{kg}$ ) by the intraperitoneal route $40 \mathrm{~min}$ before the formalin caused an antinociceptive effect $(P<0.001)$ in both the early and late phases of formalin-induced hypernociception in rats. Injection of indomethacin $(5 \mathrm{mg} / \mathrm{kg} \mathrm{IP})$ produced a significant $(P<0.001)$ antinociceptive effect in both the early and late phases of formalin
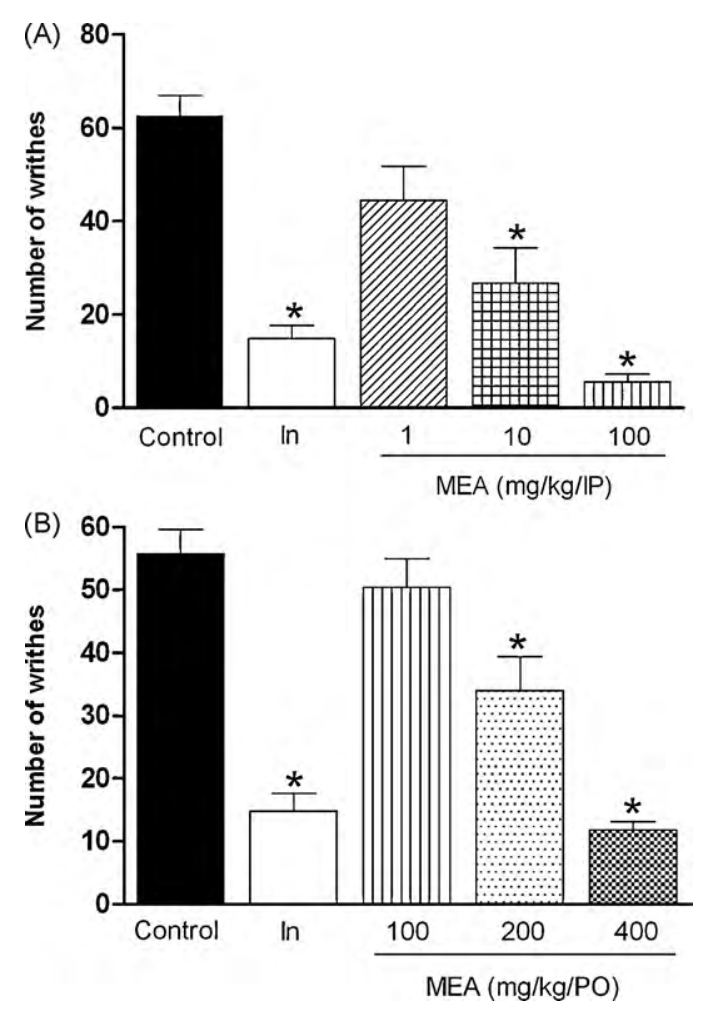

Fig. 1. Effects of intraperitoneal or oral administration of Adiantum latifolium Lam. methanolic extract (MEA) on acetic acid-induced writhing in mice. Mice were treated by intraperitoneal route (A) or oral route (B) with MEA or saline (control group). Indomethacin (In; $10 \mathrm{mg} / \mathrm{kg} \mathrm{IP}$ ) was the reference drug. All drugs were administrated $40 \mathrm{~min}$ before the acetic acid injection. Data are expressed as means \pm S.E.M.; $n=6$ mice per group. *Significantly different from control group $(P<0.001)$. ANOVA followed by Tukey's test. 

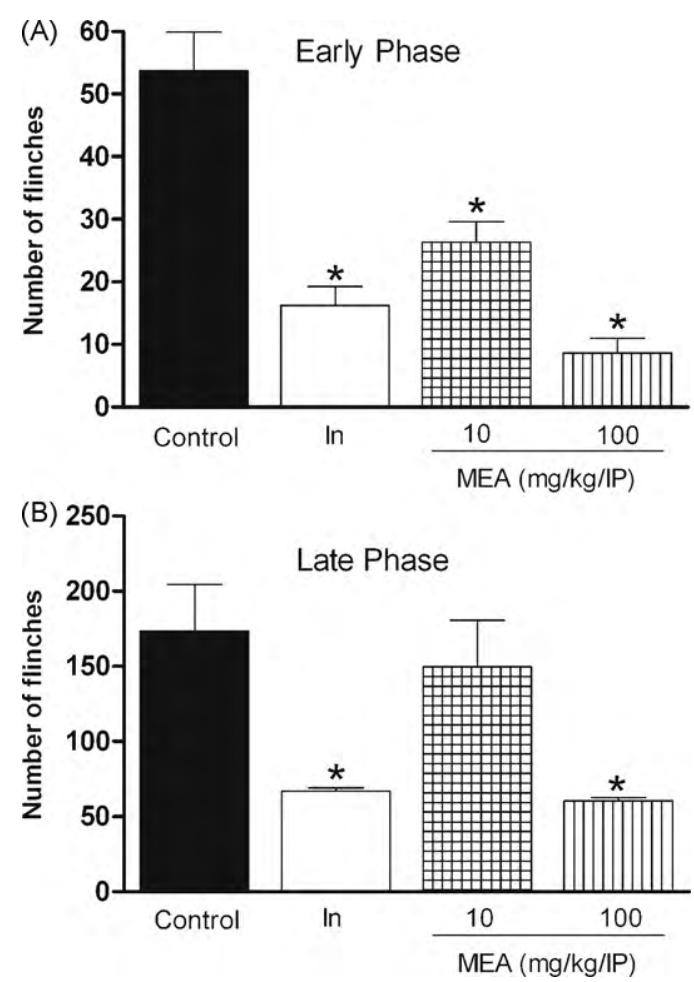

Fig. 2. Effects of Adiantum latifolium Lam. methanolic extract (MEA) treatment on inflammatory pain induced by formalin in rats. Panels (A) and (B) represent effects of MEA on the early and late phases of formalin test, respectively. Rats were treated with MEA, saline (control group), or indomethacin ( $\mathrm{In} ; 5 \mathrm{mg} / \mathrm{kg}$ ), by intraperitoneal route 40 min before formalin. Data are expressed as means \pm S.E.M.; $n=6$ rats per group. *Significantly different from control group $(P<0.001)$. ANOVA followed by Tukey's test.

test. In a different way, MEA (10 and $100 \mathrm{mg} / \mathrm{kg}$ IP) did not alter the latency response to the tail-flick test. In contrast, morphine ( $5 \mathrm{mg} / \mathrm{kg} \mathrm{SC}$ ) caused a significant increase in the latency response (data not shown).

\subsection{Antiinflammatory effects of MEA}

The antiinflammatory effect of MEA was evaluated in the carrageenan-induced paw edema model. The administration of MEA ( 100 and $200 \mathrm{mg} / \mathrm{kg}$ IP) in mice $40 \mathrm{~min}$ (data not shown) or $4 \mathrm{~h}$ (Fig. $3 \mathrm{~A}$ ) before carrageenan reduced significantly the paw edema. Since the full antiinflammatory effect of MEA was observed at $4 \mathrm{~h}$ of pre-treatment, this time was chosen for the next experiments. The administration of MEA (100 and $200 \mathrm{mg} / \mathrm{kg}$ IP) $4 \mathrm{~h}$ before carrageenan reduced significantly the paw edema $2,4,24$, and $48 \mathrm{~h}$ after the carrageenan injection (Fig. 3A). Similarly, the paw edema was inhibited at $2,4,24$ and $48 \mathrm{~h}(P<0.001)$ by pre-treatment $(4 \mathrm{~h}$ before) with dexamethasone $(0.7 \mathrm{mg} / \mathrm{kg} \mathrm{SC})$.

Next, it was investigated whether the antiinflammatory effect of MEA involves a reduction of interleukin-1 $\beta$, a proinflammatory cytokine. The results in Fig. 3B show that the administration of MEA (100 and $200 \mathrm{mg} / \mathrm{kg}$ IP) or dexamethasone $(0.7 \mathrm{mg} / \mathrm{kg} \mathrm{SC}) 4 \mathrm{~h}$ before the carrageenan injection reduces significantly $(P<0.001)$ the interleukin-1 $\beta$ levels in the inflamed paws, when compared with the vehicle-treated group. Furthermore, MEA also had antiinflammatory effects in the ear edema model (Fig. 4A). The administration of MEA $(200 \mathrm{mg} / \mathrm{kg}$ IP) $4 \mathrm{~h}$ before the arachidonic acid injection reduced significantly $(P<0.01)$ the ear edema. The injection of arachidonic acid caused a dramatic increase in interleukin$1 \beta$ levels in the ear $1 \mathrm{~h}$ after challenge (Fig. 4B). The levels of interleukin-1 $\beta$ in MEA-treated (200 mg/kg IP) or dexamethasone- treated $(0.7 \mathrm{mg} / \mathrm{kg} \mathrm{SC})$ mice were significantly reduced $(P<0.01)$ when compared to the control group.

\subsection{Acute toxicity and motor performance}

Over the study duration of 14 days, there were no deaths recorded in the groups of mice given 100 or $1000 \mathrm{mg} / \mathrm{kg}$ IP of MEA. During the observation period, MEA administration did not induce any variations in the general appearance or toxic signs in the animals.

In the rota rod test, MEA-treated mice did not show any significant motor performance alterations with the dose of $200 \mathrm{mg} / \mathrm{kg}$ IP $(113.1 \pm 3.6 \mathrm{~s})$ when compared to control mice $(105.4 \pm 8.1 \mathrm{~s})$. As expected, injection of the central nervous system depressant diazepam $(10 \mathrm{mg} / \mathrm{kg} \mathrm{IP})$ reduced the time of mice on the rota rod after 30 min of treatment $(6.1 \pm 1.9 \mathrm{~s})$.

\section{Discussion}

The present study demonstrates, for the first time, that systemic administration of MEA, at doses that did not induce any motor performance alteration, produced consistent antinociceptive and antiinflammatory effects in different models of pain and inflammation, probably by interfering with IL- $1 \beta$ release.

Intraperitoneal administration of MEA produced a dose-related antinociception when assessed in writhing test in mice. Oral administration of MEA was less potent and efficacious than its intraperitoneal administration in preventing the nociception induced by acetic acid. In fact, the bioavailability of active substances may be decreased when given orally, due to the instability in gastric and intestinal fluids and/or poor absorption in the gastrointestinal tract (Kofi-Tsekpo, 1994). The writhing test has long been used as a screening tool for the assessment of analgesic or antiinflammatory properties of new substances (Collier et al., 1968). This method presents a good sensitivity, although it has poor specificity. To avoid misinterpretation of the results, in the present study the antinociceptive effects of MEA were confirmed in the formalin test, a model of inflammatory pain which has two distinctive phases which may indicate different types of pain (Hunskaar and Hole, 1987). The early and late phases of formalin test have obvious differential properties, and therefore this test is useful not only for assessing the analgesic substances, but also for elucidating the mechanism of analgesia (Shibata et al., 1989). The early phase, named non-inflammatory pain, is a result of direct stimulation of nociceptors and reflects centrally-mediated pain; the late phase, named inflammatory pain, is caused by local inflammation with a release of inflammatory and hyperalgesic mediators (Hunskaar and Hole, 1987). In the present study, MEA administration induced antinociceptive activity both in the early and late phases of formalin test. Considering the inhibitory property of MEA on the second phase of formalin, it is possible that its antinociceptive activity is due, at least in part, to an antiinflammatory action. In line with this idea, the treatment with MEA did not prevent the nociception in the tail-flick test. The thermal model of the tail-flick test is considered to be a spinal reflex, but could also involve higher neural structures, and therefore this method identifies mainly central analgesics (Jensen and Yaksh, 1986; Le Bars et al., 2001). The fact that MEA did not induce antinociceptive effect in the tail-flick test suggests that MEA does not block the neural transmission of pain, like morphine does, and may induce a peripheral analgesia. Moreover, relaxing or motor deficit effects were discarded, since MEA administration, at the therapeutic doses, did not affect the motor performance of the mice, as tested in the rota rod test. This result corroborates the antinociceptive effect of MEA suggested by the nociceptive tests. 


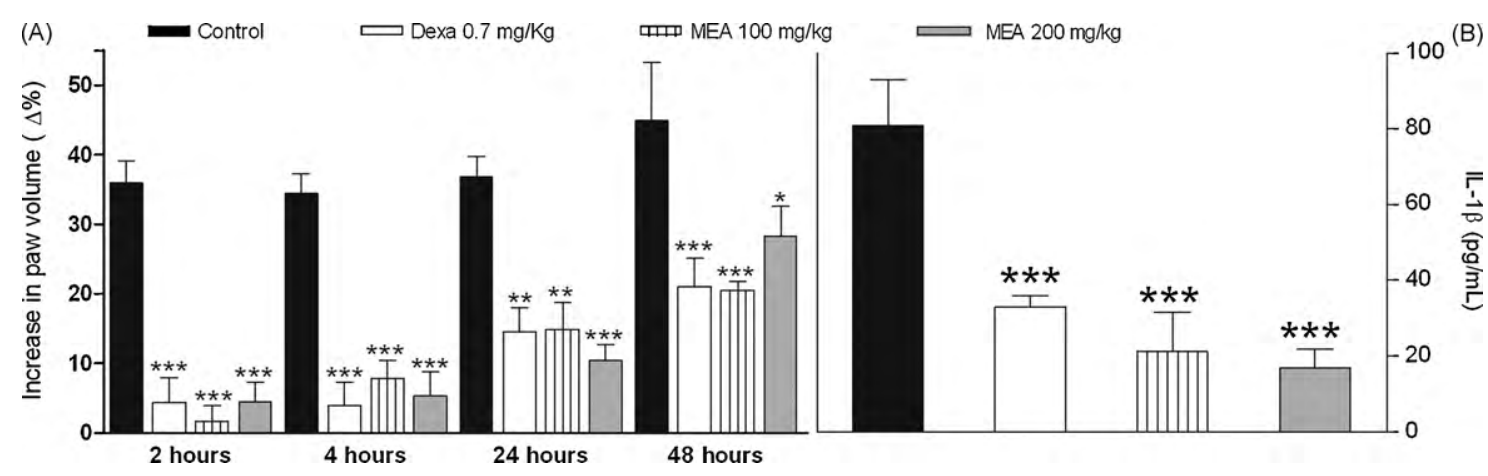

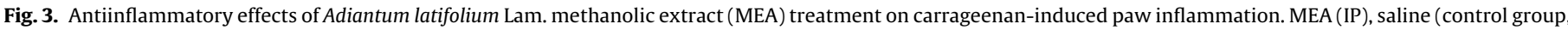

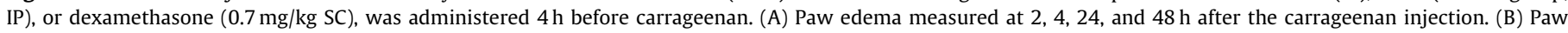

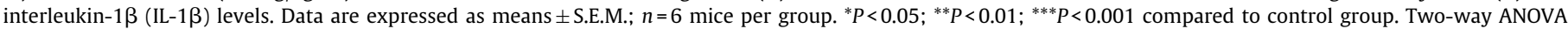
followed by Bonferroni's test.

To evaluate the antiinflammatory property of MEA, the effects of MEA treatment were assessed on two prominent experimental models used for screening of new antiinflammatory drugs: the carrageenan-induced paw edema and the arachidonic acid-induced ear edema (Sugishita et al., 1981; Carlson et al., 1985; Posadas et al., 2004). The injection of carrageenan in mice produces a typical biphasic edema associated with the production of several inflammatory mediators, such as bradykinin, prostaglandins, nitric oxide, and cytokines (Di Rosa et al., 1971; Henriques et al., 1987; Vinger et al., 1987; Posadas et al., 2004; Rocha et al., 2006). The MEA administration resulted in a marked inhibition of important events related to the inflammatory response induced by carrageenan, such as edema and increase in tissue IL-1 $\beta$ levels. Nowadays, it is well accepted that cytokines constitute a link between cellular injuries or immunological recognition and the local or systemic signs of inflammation, e.g. cell migration, edema, fever, and hyperalgesia (Ferreira et al., 1988; Faccioli et al., 1990; Dinarello, 2000). Different cell types, including macrophages, monocytes, and glial cells produce IL-1 $\beta$, which in turn induces the production of other inflammatory mediators involved with cellular recruitment, fever, acute phase protein release, and increase of vascular permeability (Dinarello, 1998). Considering the important role of IL-1 $\beta$ during the inflammatory response, it is possible suggested that the antiinflammatory effect of MEA may be related to their ability to inhibit the release of IL-1 $\beta$.

A key role of IL-1 $\beta$ on inflammatory hypernociception also has been demonstrated. IL-1 $\beta$ stimulates the expression of COX2 and the subsequent release of prostaglandins (Zucali et al., 1986; Crofford et al., 1994), involved with nociceptive sensitization (Handwerker, 1976; Ferreira and Nakamura, 1979). Corroborating this idea, the local injection of IL-1 $\beta$ produces hypernociception depends on the release of prostanoids (Ferreira et al., 1988). In the present work, the MEA treatment reduced the IL-1 $\beta$ levels. Because the inhibition of IL- $1 \beta$ release might lead to the inhibition of prostanoids production, it is possible that MEA acts by preventing the nociceptive sensitization through the inhibition of the production of mediators that sensitize the nociceptor. Since the sensitization of nociceptors is the common denominator of different types of pain (Hucho and Levine, 2007), the reduction of IL-1 $\beta$ levels can be responsible to the antinociceptive effect of MEA described herein.

In the present study, a single administration of MEA produced antiinflammatory effects until $48 \mathrm{~h}$ after its administration, suggesting a relatively long-lasting antiinflammatory action. In addition, the full antiinflammatory effect of MEA was observed $4 \mathrm{~h}$ after its administration. This delayed antiinflammatory effect could indicate its dependence on the modulation of transcriptional factors and de novo synthesis of proteins involved in the inflammatory response. In fact, a property common to several cytokines is the induction of a positive feedback mechanism, as well as the induction of other cytokines and inflammatory mediators (Dinarello, 2000 , 2007). IL-1 induces the production of IL-1, IL-6, IL-8, adhesion molecules, chemokines, nitric oxide synthase, and COX-2, all relevant molecules to inflammatory responses (Dinarello et al., 1987; Van Damme et al., 1987; Ferreira et al., 1988; Cunha et al., 1991). Therefore, the delayed antiinflammatory effect of MEA may reflect an interference with the synthesis of the cytokine cascade and inflammatory proteins modulated by IL- $1 \beta$ during the inflammatory response.

Confirming the antiinflammatory activity of MEA, the edema induced by arachidonic acid was inhibited to a significant extent by the extract, and this inhibition was accompanied by a reduc-
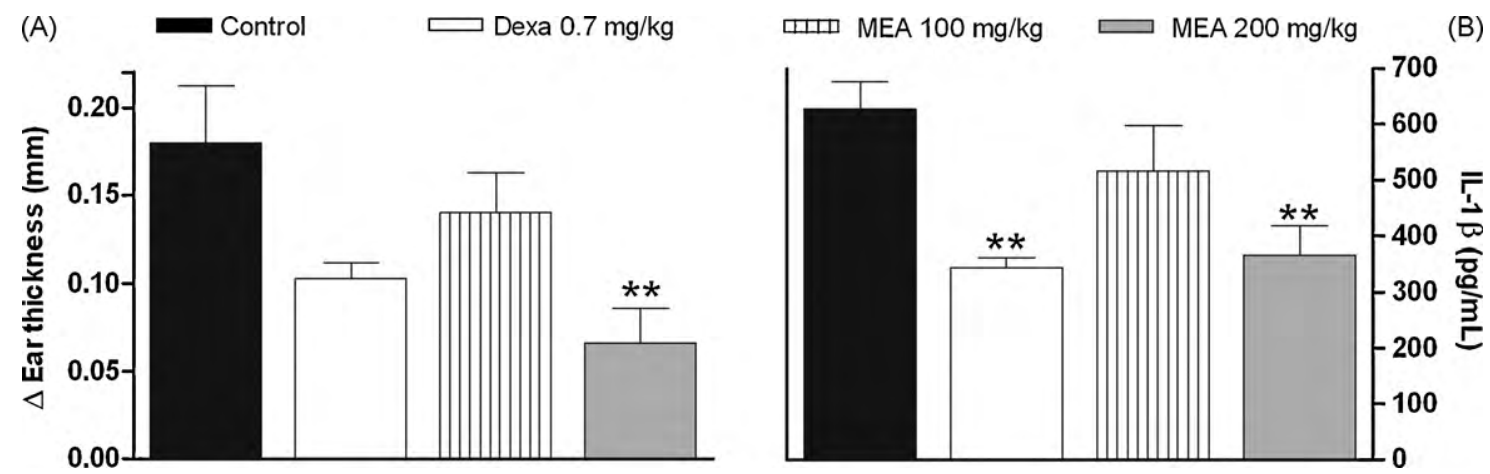

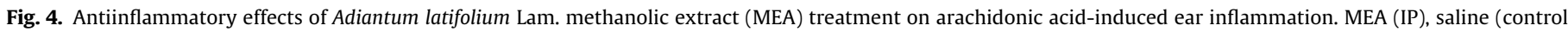

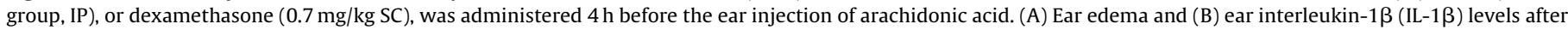
arachidonic acid. Data are expressed as means \pm S.E.M.; $n=6$ mice per group. ${ }^{*} P<0.05 ;{ }^{* *} P<0.01$ compared to control group. ANOVA followed by Tukey's test. 
tion of IL-1 $\beta$ levels. Importantly, in both models of inflammation used in the present study, the edema inhibition and reduction of IL-1 $\beta$ levels were significant at similar doses, suggesting that the antiinflammatory effect of MEA is dependent on IL- $1 \beta$ inhibition. The local administration of arachidonic acid on mouse ears induces the synthesis of prostaglandin $\mathrm{E}_{2}$ and leukotrienes $\mathrm{C}_{4}$ and $\mathrm{D}_{4}$ (Opas et al., 1985). The synthesis of these arachidonic acid metabolites precedes or is coincident with increased vascular permeability, resulting in an edematous response (Carlson et al., 1985; Opas et al., $1985)$. Moreover, the IL- $1 \beta$ expression is enhanced by local treatment with arachidonic acid (Chi et al., 2003), and a single injection of IL-1 $\beta$ antibody suppresses the development of arachidonic acidinduced ear edema (Bäck et al., 1989). These data suggest a key role of IL-1 $\beta$ on arachidonic acid-induced edema and are in line with the present results.

Recently, there has been renewed interest in botanically derived products as sources of therapeutic agent due to safety concerns with synthetic drugs. In contrast with non-steroidal antiinflammatory agents, inhibitors of cytokine production exhibit disease-modifying activities in animal models of chronic inflammation (Geiger et al., 1994). Thus, the down-regulation of cytokines by non-toxic agents is a therapeutic strategy for the control of inflammatory diseases. The results presented herein strongly suggest that Adiantum latifolium Lam. possesses analgesic and antiinflammatory activities associated with inhibition of IL-1 $\beta$ release, constituting an attractive possibility to pharmacological development. Furthermore, the acute toxicity does not show any symptoms, changes in behavior or mortality at $1 \mathrm{~g} / \mathrm{kg}$ doses, suggesting a therapeutic safety for the doses pharmacologically active. The precise mechanisms through which MEA exerts its action, as well as the compounds present in this extract responsible for this activity, are currently under investigation.

\section{Acknowledgements}

This work was supported by CNPq, FAPESB, IMSEAR, RENORBIO, FINEP, MCT and FIOCRUZ.

\section{References}

Bäck, O., Newton, R.C., Huang, J.J., Lima, T.J., 1989. Systematical interleukin I administration suppresses arachidonic acid-induced ear oedema in the mouse. The British Journal of Dermatology 121, 701-707.

Barros, I.C.L., Andrade, L.H.C., 1997. Pteridófitas medicinais (samambaias, avencas e plantas afins). Ed. Universitária da Universidade Federal de Pernambuco, Recife.

Bourbonnais-Spear, N., Awad, R., Merali, Z., Maquin, P., Cal, V., Arnason, J.T., 2007. Ethnopharmacological investigation of plants used to treat susto, a folk illness. Journal of Ethnopharmacology 109, 380-387.

Bresciani, L.F., Priebe, J.P., Yunes, R.A., Dal Magro, J., Delle Monache, F., de Campos, F., de Souza, M.M., Cechinel-Filho, V., 2003. Pharmacological and phytochemical evaluation of Adiantum ceneatum growing in Brazil. Zeitschrift für Naturforschung C. Journal of Biosciences 58, 191-194.

Cambie, R.C., Ash, J., 1994. Fijian Medicinal Plants. Commonwealth Scientific and Industrial Research Organisation, Melbourne.

Carlson, R.P., O'Neill-Davis, L., Chang, J., Lewis, A.J., 1985. Modulation of mouse ear oedema by cyclooxygenase and lipoxygenase inhibitors and other pharmacologic agents. Agents and Actions 17, 197-204.

Chi, Y.S., Lim, H., Park, H., Kim, H.P., 2003. Effects of wogonin, a plant flavone from Scutellaria radix, on skin inflammation: in vivo regulation of inflammationassociated gene expression. Biochemical Pharmacology 66, 1271-1278.

Christensen, H., 1997. Uses of ferns in two indigenous communities in Sarawak, Malaysia. In: Johns, R.J. (Ed.), Holttum Memorial Volume. Royal Botanic Gardens, Kew, pp. 177-192.

Collier, H.O., Dinneen, L.C., Johnson, C.A., Schneider, C., 1968. The abdominal constriction response and its suppression by analgesic drugs in the mouse. British Journal of Pharmacology and Chemotherapy 32, 295-310.

Crofford, L.J., Wilder, R.L., Ristimaki, A.P., Sano, H., Remmers, E.F., Epps, H.R., Hla, T., 1994. Cyclooxygenase-1 and -2 expression in rheumatoid synovial tissues. Effects of interleukin-1 beta, phorbol ester, and corticosteroids. The Journal of Clinical Investigation 93, 1095-1101.

Crummey, A., Harper, G.P., Boyle, E.A., Mangan, F.R., 1987. Inhibition of arachidonic acid-induced ear oedema as a model for assessing topical anti-inflammatory compounds. Agents and Actions 20,69-76.
Cunha, F.Q., Lorenzetti, B.B., Poole, S., Ferreira, S.H., 1991. Interleukin-8 as a mediator of sympathetic pain. British Journal of Pharmacology 104, 765-767.

D'Amour, F.E., Smith, D.L., 1941. A method for determining loss of pain sensation. The Journal of Pharmacology and Experimental Therapeutics 72, 74-79.

Dinarello, C.A., 1998. Interleukin-1, interleukin-1 receptors and interleukin-1 receptor antagonist. International Reviews of Immunology 16, 457-499.

Dinarello, C.A., 2000. Proinflammatory cytokines. Chest 118, 503-508.

Dinarello, C.A., 2007. Historical insights into cytokines. European Journal of Immunology 1, S34-45.

Dinarello, C.A., Ikejima, T., Warner, S.J.C., Orencole, S.F., Lonnemann, G., Cannon, J.G., Libby, P., 1987. Interleukin 1 induces interleukin 1. I. Induction of circulating interleukin I in rabbits in vivo and in human mononuclear cells in vitro. Journal of Immunology 139, 1902-1910.

Di Rosa, M., Giroud, J.P., Willoughby, D.A., 1971. Studies on the mediators of the acute inflammatory response induced in rats in different sites by carrageenan and turpentine. The Journal of Pathology 104, 15-29.

Dogné, J.M., Supuran, C.T., Pratico, D., 2005. Adverse cardiovascular effects of the coxibs. Journal of Medicinal Chemistry 48, 2251-2257.

Dubuisson, D., Dennis, S.G., 1977. The formalin test: a quantitative study of the analgesic effects of morphine, meperidine and brain-stem stimulation in rats and cats. Pain 4, 161-174.

Faccioli, L.H., Souza, G.E., Cunha, F.Q., Poole, S., Ferreira, S.H., 1990. Recombinant interleukin-1 and tumour necrosis factor induce neutrophil migration 'in vivo' by indirect mechanisms. Agents and Actions 30, 344-349.

Ferreira, S.H., Lorenzetti, B.B., Bristow, A.F., Poole, S., 1988. Interleukin-1 beta as a potent hyperalgesic agent antagonized by a tripeptide analogue. Nature 334 698-700.

Ferreira, S.H., Nakamura, M., 1979. I - Prostaglandin hyperalgesia, a cAMP/Ca ${ }^{2+}$ dependent process. Prostaglandins 18, 179-190.

Geiger, T., Rordorf, C., Cosenti-Vargas, A., Ferrini, P.G., Widler, L., Glatt, M., Vosbeck, K., 1994. CGP 47969A: effect on collagen induced arthritis in DBA/1 mice. The Journal of Rheumatology 21, 1992-1997.

Gogoi, R., 2002. Ethnobotanical studies of some ferns used by the Garo Tribals of Meghalaya. Advances in Plant Sciences 15, 401-405.

Handwerker, H.O., 1976. Influences of algogenic substances and prostaglandins on the discharges of unmyelynated cutaneous nerve fibers identified as nociceptors. In: Bonica, J.J., Albe-Fessard, D. (Eds.), Advances in Pain Research and Therapy, vol. 1. Raven Press, New York, pp. 41-45.

Henriques, M.G.M.O., Silva, P.M.R., Martins, M.A., Flores, C.A., Cunha, F.Q., AssreuyFilho, J., Cordeiro, R.S.B., 1987. Mouse paw oedema. A new model for inflammation? Brazilian Journal of Medical and Biological Research 20, 243249.

Hucho, T., Levine, J.D., 2007. Signaling pathways in sensitization: toward a nociceptor cell biology. Neuron 55, 365-376.

Hunskaar, S., Hole, K., 1987. The formalin test in mice: dissociation between inflammatory and non-inflammatory pain. Pain 30,103-114

IMS Health, 2005. IMS National Sales Perspectives ${ }^{\mathrm{TM}}$, 2/2005.

Jensen, T.S., Yaksh, T.L., 1986. Comparison of antinociceptive action of morphine in the periaqueductal gray, medial and paramedial in rat. Brain Research 363, 99-113.

Kofi-Tsekpo, M.W., 1994. Optimization of pharmaceutical formulations for therapy African Journal of Health Sciences 1, 13-19.

Le Bars, D., Gozariu, M., Cadden, S., 2001. Animal models of nociception. Pharmacological Reviews 53, 628-651.

Lopez, A., Hudson, J.B., Towers, G.H.N., 2001. Antiviral and antimicrobial activities of Colombial medicinal plants. Journal of Ethnopharmacology 77, 189-196.

Lorke, D., 1983. A new approach to practical acute toxicity testing. Archives of Toxicology 54, 275-287.

Moran, R.C., Yatskievych, G., 1995. Pteridaceae. In: Moran, R.C., Riba, R. (Eds.), Flora Mesoamericana. Vol. 1. Psilotaceae a Salviniaceae. Universidad Nacional Autónoma de México, México, pp. 104-145.

Opas, E.E., Bonney, R.J., Humes, J.L., 1985. Prostaglandin and leukotriene synthesis in mouse ears inflamed by arachidonic acid. Journal of Investigative Dermatology $84,253-256$.

Peskar, B.M., 1977. On the synthesis of prostaglandins by human gastric mucosa and its modification by drugs. Biochimica et Biophysica Acta 487, 307-314.

Posadas, I., Bucci, M., Roviezzo, F., Rossi, A., Parente, L., Sautebin, L., Cirino, G., 2004 Carrageenan-induced mouse paw edema is biphasic, age-weight dependent and displays differential nitric oxide cyclooxygenase-2 expression. British Journal of Pharmacology 142, 331-338.

Robert, A., 1976. Antisecretory, antiulcer, cytoprotective and diarrheogenic properties of prostaglandins. Advances in Prostaglandin and Thromboxane Research 2 , 507-520.

Rocha, A.C.C., Fernandes, E.S., Quintão, N.L.M., Campos, M.M., Calixto, J.B., 2006 Relevance of tumour necrosis factor-a for the inflammatory and nociceptive responses evoked by carrageenan in the mouse paw. British Journal of Pharmacology 148, 688-695.

Santiago, H.C., Pires, M.F.B., Souza, D.G., Roffe, E., Côrtes, D.F., Tafuri, W.L., Teixeira, M.M., Vieira, L.Q., 2006. Platelet activating factor receptor-deficient mice present delayed interferon-g upregulation and high susceptibility to Leishmania amazonensis infection. Microbes and Infection 8, 2569-2577.

Shibata, M., Ohkubo, T., Takahaski, H., Inoki, R., 1989. Modified formalin test: characteristic biphasic pain response. Pain 38, 347-352.

Sugishita, E., Amagaya, S., Ogihara, Y., 1981. Antiinflammatory testing methods: comparative evaluation of mice and rats. Journal of Pharmacobio-dynamics 4 565-575. 
Tapiero, H., Ba, G.N., Couvreur, P., Tew, K.D., 2002. Polyunsaturated fatty acids (PUFA) and eicosanoids in human health and pathologies. Biomedicine $\&$ Pharmacotherapy 56, 215-222.

Van Damme, J., Opdenakker, G., Simpson, R.J., Rubira, M.R., Cayphas, S., Vink, A., Billiau, A., Snick, J.V., 1987. Identification of the human 26-kD protein, interferon beta 2 (IFN-beta 2), as a B cell hybridoma/plasmacytoma growth factor induced by interleukin 1 and tumor necrosis factor. The Journal of Experimental Medicine $165,914-919$.

Vaz, Z.R., Filho, V.C., Yunes, R.A., Calixto, J.B., 1996. Antinociceptive action of 2(4-bromobenzoyl)-3-methyl-4,6-dimethoxy benzofuran, a novel xanthoxyline derivative on chemical and thermal models of nociception in mice. Journal of Pharmacology and Experimental Therapeutics 278, 304-312.

Vinger, R., Truax, J.F., Selph, J.L., Jonhston, P.R., Venable, A.L., Mckenzie, R.K., 1987. Pathway to carrageenan-induced inflammation in the hind limb of the rat. Federation Proceedings 46, 118-126.
Winter, C.A., Risley, E.A., Nuss, G.W., 1962. Carrageenan-induced edema in hind paw of the rat as an assay for antiinflammatory drugs. Proceedings of the Society for Experimental Biology and Medicine 111, 544-547.

Winter, S.L.S., Mynssen, C.M., Prado, J., 2007. Adiantum (Pteridaceae) no arboreto do Jardim Botânico do Rio de Janeiro, Brasil. Rodriguésia 58, 847858 .

Young, J.M., Spires, D.A., Bedord, C.J., Wagner, B., Ballaron, S.J., De Young, L.M., 1984 The mouse ear inflammatory response to topical arachidonic acid. Journal of Investigative Dermatology 82, 367-371.

Zimmermann, M., 1983. Ethical guidelines for investigations of experimental pain in conscious animals. Pain 16, 109-110.

Zucali, J.R., Dinarello, C.A., Oblon, D.J., Gross, M.A., Anderson, L., Weiner, R.S., 1986. Interleukin 1 stimulates fibroblasts to produce granulocyte-macrophage colonystimulating activity and prostaglandin E2. Journal of Clinical Investigation 77, 1857-1863. 